\title{
Differences in Progress of Rigor Mortis between Cultured Red Sea Bream and Cultured Japanese Flounder
}

\author{
Kyung Hee Lee, ${ }^{* 1}$ Mutsuyosi Tsuchimoto, ${ }^{* 1}$ Takahiro Onishi, ${ }^{* 2}$ Zi-hua Wu, ${ }^{* 1}$ \\ Abdul Jabarsyah, ${ }^{* 1}$ Tosio Misima, ${ }^{* 1}$ Katsuyasu Tachibana ${ }^{* 1}$ \\ ${ }^{*}$ Laboratory of Fishery Nutritional Sciences, Graduate School of Marine Science Engineering, \\ Nagasaki University, Nagasaki 852 , Japan \\ ${ }^{* 2}$ Laboratory of Fishery Nutritional Sciences, Faculty of Fisheries, Nagasaki University, \\ Nagasaki 852-8131, Japan
}

(Received August 11, 1997)

\begin{abstract}
As a part of the study program to clarify the cause of differences in rigor mortis among other fishes, the temporal changes of muscular contraction in the pillar form of muscle were measured at various storage temperatures in cultured red sea bream and cultured Japanese flounder acclimated at a habitat temperature of $25^{\circ} \mathrm{C}$, and the discrepancies in the progress of muscular contraction were examined between both fishes. To examine in detail the temporal changes of muscular contraction at various storage temperatures and then between both fishes, the temporal changes were applied to straight regression lines within the range until reaching a peak of muscular contraction. These regression lines closely matched the actual measurement values. In both fish species, the slope value, the speed of progression of muscular contraction, slowed with the decrease of storage temperature within the range from $25^{\circ} \mathrm{C}$ to $12^{\circ} \mathrm{C}$; on the contrary, within the range under $10^{\circ} \mathrm{C}$, it became faster. The progression speed and level of muscular contraction were faster and higher in cultured red sea bream than in cultured Japanese flounder at various storage temperatures. The cold rigor mortis in both fishes, however, appeared equally at storage temperature near $10^{\circ} \mathrm{C}$.
\end{abstract}

Key words: cultured red sea bream, cultured Japanese flounder, rigor mortis, cold rigor mortis, muscular contraction

The progress of rigor mortis in fish has attracted the attention of many researchers, and it has been reported that the speed of progression differs among fish species, ${ }^{1-37}$ storage temperatures, ${ }^{1,4-8)}$ and killing procedures, ${ }^{9-12)}$ as well as between cultured wild fish ${ }^{4,13)}$ and among habitat temperatures ${ }^{14-17)}$ in the same fish species. Meanwhile, it is generally known that rigor mortis occurs when muscle extension vanishes through the irresistible coupling of actin and myosin by the consumption of ATP as energy matter. Iwamoto et al. ${ }^{1,4,5,12)}$ analyzed ATP resolution and lactate accumulation in muscle with the progress of rigor mortis in red sea bream, Japanese flounder, and several sea water fishes. They reported that not only the progression speed of rigor mortis but also both ATP resolution and lactate accumulation were faster in fish stored at $0^{\circ} \mathrm{C}$ than in fish stored at $10^{\circ} \mathrm{C}$ in all of the fish species. However, they found almost no correlation between the progression speed of rigor mortis and the total amounts of ATP resolution. Regarding the correlation between the progression speed of rigor mortis and the acclimation temperature, Watabe et al. ${ }^{14,16,17)}$ reported that carp acclimated to low temperature $\left(10^{\circ} \mathrm{C}\right)$ exhibited not only a more rapid progress of rigor mortis, but also higher $\mathrm{Mg}^{2+}$-ATPase activity of myofibril and $\mathrm{Ca}^{2+}$ uptake rate of sarcoplasmic reticulum than carp acclimated to high temperature $\left(30^{\circ} \mathrm{C}\right)$. Furthermore, they considered that $\mathrm{Ca}^{2+}$ concentration surrounding myofibril might be increased rapidly in carp acclimated to low temperature $\left(10^{\circ} \mathrm{C}\right)$ than in carp acclimated to high temperature $\left(30^{\circ} \mathrm{C}\right)$, and the difference in the speed of progress of rigor mortis between the two groups of carp might be a result of the gradually enhanced $\mathrm{Mg}^{2+}$-ATPase activity and accelerated ATP resolution by a more rapid rise of $\mathrm{Ca}^{2+}$ concentration surrounding myofibril in carp acclimated to low temperature $\left(10^{\circ} \mathrm{C}\right)$. Therefore, though the relationship between the progression speed of rigor mortis and the total amounts of ATP resolution has been recognized distinctly in the same fish species, in different fish species it has not been recognized. In other words, though the difference of progression speed and strength in rigor mortis among other fish species has already been recognized, the cause has not been studied.

Therefore, we attempted to clarify the cause of the difference in rigor mortis between cultured red sea bream and cultured Japanese flounder. As a part of this study program, we particularly examined the discrepancies in the progress of muscular contraction for both fish species.

\section{Experimental Methods}

\section{Sample Fish}

Cultured red sea bream Pagrus major and cultured Japanese flounder Paralichthys olivaceus, which have been already shown to be remarkably different in the progression speed and pattern of rigor mortis, were used as sample fish species. The 2-year-old fish had been cultivated at Toisu Bay, Nagasaki prefecture, and were purchased from a fish farmer in the summer season at a habitat temperature near $25^{\circ} \mathrm{C}$. To adapt them at $25^{\circ} \mathrm{C}$ be- 


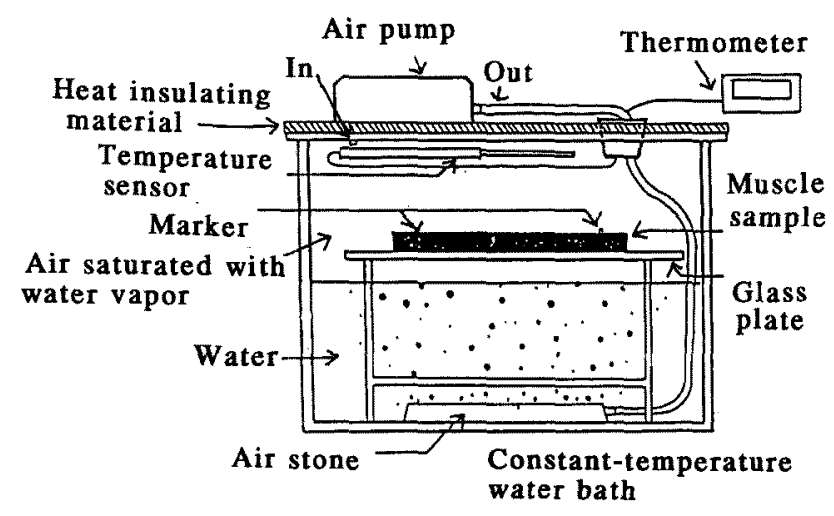

Part used to measure the change in muscular contraction

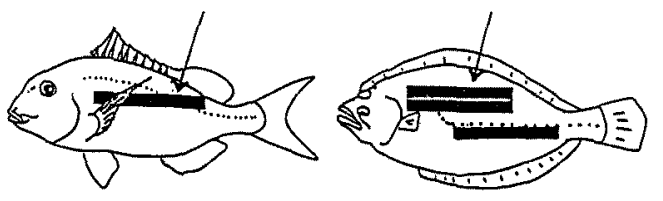

Fig. 1. The illustration of apparatus measured the changes of muscular contraction with the lapse of storage time. The muscle was arranged in a pillar form of about $1.5 \mathrm{~cm} \times 1.5 \mathrm{~cm}$ in cross section and about $10 \mathrm{~cm}$ in length with scales, skin, and dark muscle, and then was placed facing scale side downward on the glass plate in a constanttemperature water bath saturated with water vapor.

cause of the slightly irregular time for purchase, they were held in a laboratory tank with water at a habitat temperature of $25^{\circ} \mathrm{C}$ for 2 months or more. They were fed moist pellets daily and were used as experimental sample fish.

\section{Measurement of Contractile Percentage in Muscle}

The sample fish were killed by cutting the hind brain after being anesthetized in sea water containing MS-222 $(100 \mathrm{ppm})$. The dorsal muscles, attached scales and skin then were immediately cut off in a pillar form of approximately $1.5 \times 1.5 \times 10 \mathrm{~cm}$ along the direction of the body length from both sides of the fish body in cultured red sea bream and from 2 or 3 positions of the upper side with attached eyes in cultured Japanese flounder. These regions are shown in Fig. 1.

The changes in muscle length accompanying rigor mortis were measured with the lapse of storage time, by laying the muscular scale side downward on a glass plate in a constant-temperature water bath saturated with water vapor ${ }^{18)}$ (Fig. 1). The contractile percentage of muscle was calculated as follows: $[(\mathrm{A}-\mathrm{B}) / \mathrm{A}] \times 100$, where $\mathrm{A}$ and $\mathrm{B}$ express muscle length just after killing and after passing for one time, respectively. The measurement was conducted at storage temperatures of $25,20,15,12,10,8,6,5,4$, and $3^{\circ} \mathrm{C}$. Table 1 shows detailed experiments at various storage temperatures for several pieces of the pillar form muscle cut off from the same fish body. When the muscle contracted with the lapse of time, neither adhering to the glass plate nor notable curvature of muscle were observed.

\section{Results}

\section{Temporal Changes of Muscular Contraction}

The temporal changes of muscular contraction in the pillar form of muscle at various storage temperatures are shown in Fig. 2 for cultured red sea bream and cultured Japanese flounder. These results of both fish species include different fish specimens. Comparing the progress of muscular contraction between the two fish species, the temporal change of muscular contraction in cultured red sea bream progressed faster and was higher in level than that in cultured Japanese flounder at various storage temperatures.

\section{Relationship between Storage Time and Muscular Contrac- tion}

The temporal change of muscular contractile percentage followed a straight line at various storage temperatures (Fig. 2), so we attempted to describe the temporal change by an equation. The relationship between the storage time and muscular contractile percentage within the range until reaching a peak of muscular contractile percentage is shown in Table 2 for all of the cases at various storage temperatures in both fish species. The relationship for all of the cases exhibited a positive, highly significant correlation of $p<0.001$ or $p<0.01$. These regression lines corresponded very well with the actual measurement values.

The slope of the regression line, the progression speed of muscular contraction per hour, was higher in cultured red sea bream than in cultured Japanese flounder in all of the cases at various storage temperatures, with the exception of a case at $25^{\circ} \mathrm{C}$ in cultured Japanese flounder.

Comparing the slope value among various storage temperatures in the same fish species, the slope was steepes in the order of $25^{\circ} \mathrm{C}>4^{\circ} \mathrm{C}>8^{\circ} \mathrm{C}>12^{\circ} \mathrm{C}>6^{\circ} \mathrm{C}>20^{\circ} \mathrm{C}>$ $10^{\circ} \mathrm{C}$ in cultured red sea bream and $25^{\circ} \mathrm{C}>20^{\circ} \mathrm{C}>5^{\circ} \mathrm{C}>$ $3^{\circ} \mathrm{C}>15^{\circ} \mathrm{C}>10^{\circ} \mathrm{C}>8^{\circ} \mathrm{C}>12^{\circ} \mathrm{C}$ in cultured Japanese flounder. Namely, the slope for each fish species was lowest at $10^{\circ} \mathrm{C}$ in cultured red sea bream and at $12^{\circ} \mathrm{C}$ in cultured Japanese flounder, respectively.

\section{Relationship between Storage Temperature and Slope of Regression Line}

The relationship between the storage temperature and slope of regression line is shown in Fig. 3. For both fish species, though the progression speed slowed with the decrease of storage temperature within the range from 25 to $10^{\circ} \mathrm{C}$ or $12^{\circ} \mathrm{C}$, within the range under $8^{\circ} \mathrm{C}$ or $10^{\circ} \mathrm{C}$, it became faster. Namely, the change of slope with the decrease of storage temperature in cultured red sea bream exhibited a concave parabola shape having the lowest value near a storage temperature of $10^{\circ} \mathrm{C}$. Though it is assumed that the same aspect existed in cultured Japanese flounder, the lowest value was found to be near a storage temperature of $12^{\circ} \mathrm{C}$.

\section{Temperature at which Cold Rigor Mortis Appears}

Concerning the results for the same fish specimen, the temporal values of muscular contractile percentage at $10^{\circ}$ $\mathrm{C}$ were newly plotted against those at $12^{\circ} \mathrm{C}$, as shown in Fig. 4 by fish species. For both fish species, the plotted 
Table 1. Standard body length and body weight of sample fish used for this experiment. These sample fish were reared at $25^{\circ} \mathrm{C}$ during over two months

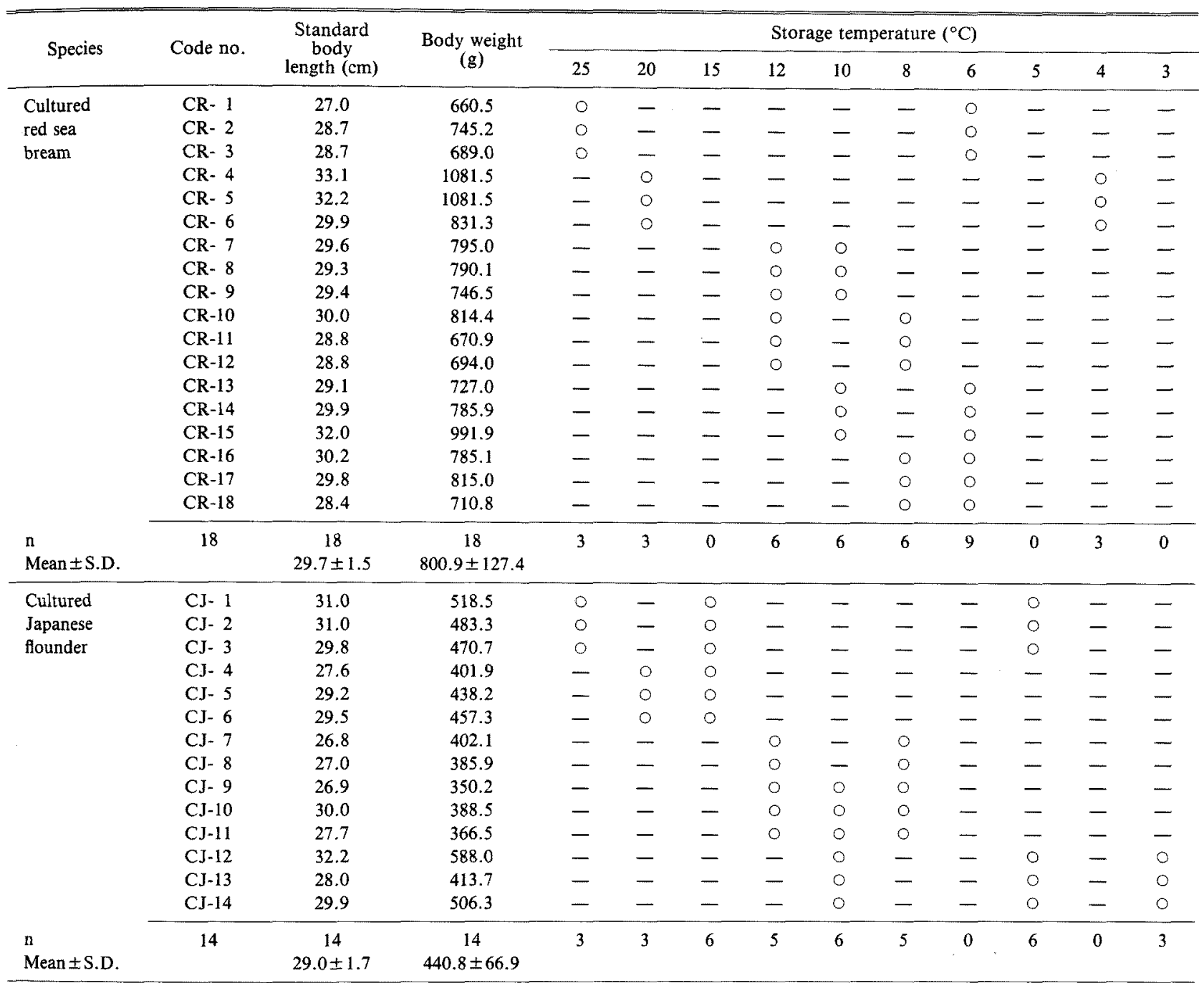

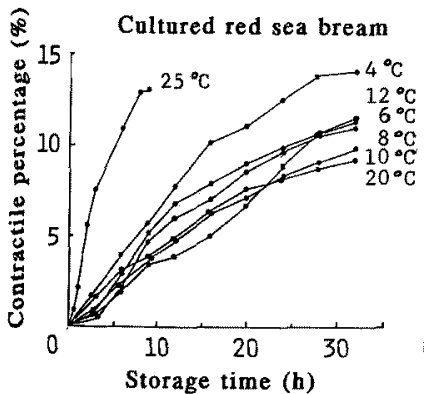

Cultured Japanese flounder

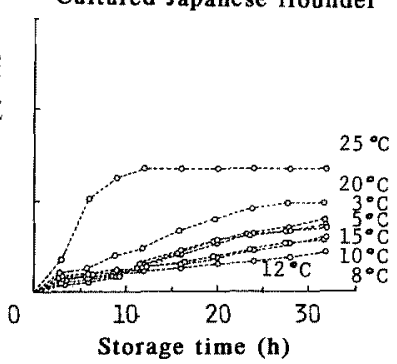

Fig. 2. The change of muscular contractile percentage with the lapse of storage time at various storage temperatures in cultured red sea bream and cultured Japanese flounder.

points were distributed above the line $\mathrm{Y}=\mathrm{X}$. Namely, the temporal levels of muscular contraction were higher at $10^{\circ} \mathrm{C}$ than at $12^{\circ} \mathrm{C}$. Furthermore, though the temporal levels for other storage temperatures are not shown, they were as follows: $25^{\circ} \mathrm{C}>6^{\circ} \mathrm{C}, 20^{\circ} \mathrm{C}<4^{\circ} \mathrm{C}, 12^{\circ} \mathrm{C}<8^{\circ} \mathrm{C}$, $10^{\circ} \mathrm{C}<6^{\circ} \mathrm{C}$, and $8^{\circ} \mathrm{C}<6^{\circ} \mathrm{C}$ in cultured red sea bream and $25^{\circ} \mathrm{C}>5^{\circ} \mathrm{C}>15^{\circ} \mathrm{C}, 20^{\circ} \mathrm{C}>15^{\circ} \mathrm{C}, 12^{\circ} \mathrm{C}<8^{\circ} \mathrm{C}$, and $10^{\circ} \mathrm{C}$ $<5^{\circ} \mathrm{C}<3^{\circ} \mathrm{C}$ in cultured Japanese flounder, respectively. These results in the same fish specimen supported the foregoing results in different fish specimens, with the exception of two cases between 10 and $12^{\circ} \mathrm{C}$ and between $8^{\circ} \mathrm{C}$ and $6^{\circ} \mathrm{C}$ in cultured red sea bream. Namely, the storage temperature at which cold rigor mortis appeared was near $10^{\circ} \mathrm{C}$ in both fish species.

\section{Discussions}

In cultured red sea bream and cultured Japanese flounder acclimated at a habitat temperature of $25^{\circ} \mathrm{C}$, the temporal changes of muscular contraction were faster in cultured red sea bream than in cultured Japanese flounder at various storage temperatures within the range from $25^{\circ} \mathrm{C}$ to near $5^{\circ} \mathrm{C}$, and the peak level also was remarkably higher in cultured red sea bream (Fig. 2). Iwamoto et al. ${ }^{4,5,13)}$ also reported a comparison of the progression speed of rigor mortis at two storage temperatures of 5 and $10^{\circ} \mathrm{C}$ between red sea bream and plaice, and found that the time of initia- 
Table 2. Relationship between storage time and muscular contractile percentage at several storage temperatures

\begin{tabular}{|c|c|c|c|c|c|c|}
\hline \multirow[t]{2}{*}{ Species } & \multirow{2}{*}{$\begin{array}{l}\text { Storage } \\
\text { temp. } \\
\left({ }^{\circ} \mathrm{C}\right)\end{array}$} & \multirow{2}{*}{$\begin{array}{l}\text { Range of } \\
\text { storage } \\
\text { time (h) }\end{array}$} & \multirow[t]{2}{*}{$\mathrm{n}$} & \multicolumn{3}{|c|}{$\begin{array}{l}\text { Parameters of correlation } \\
\text { between storage time and } \\
\text { contractile percentage }\end{array}$} \\
\hline & & & & Slope & Intercept & $\mathrm{r}$ \\
\hline \multirow{7}{*}{$\begin{array}{l}\text { Cultured red } \\
\text { sea bream }\end{array}$} & 25 & $0-9$ & 10 & 1.339 & 2.372 & $0.962^{* * *}$ \\
\hline & 20 & $0-28$ & 9 & 0.309 & 0.849 & $0.984^{* * *}$ \\
\hline & 12 & $0-32$ & 10 & 0.372 & -0.297 & $0.995^{* * *}$ \\
\hline & 10 & $0-44$ & 13 & 0.285 & 0.803 & $0.991^{* * *}$ \\
\hline & 8 & $0-28$ & 9 & 0.397 & 0.245 & $0.984^{* * *}$ \\
\hline & 6 & $0-32$ & 10 & 0.363 & 0.972 & $0.967^{* * *}$ \\
\hline & 4 & $0-28$ & 9 & 0.501 & 0.816 & $0.987^{* * *}$ \\
\hline \multirow{8}{*}{$\begin{array}{l}\text { Cultured } \\
\text { Japanese } \\
\text { flounder }\end{array}$} & 25 & $0-12$ & 5 & 0.595 & 0.378 & $0.964^{* *}$ \\
\hline & 20 & $0-20$ & 7 & 0.190 & 0.179 & $0.994^{* * *}$ \\
\hline & 15 & $0-32$ & 10 & 0.117 & 0.030 & $0.990^{* * *}$ \\
\hline & 12 & $0-32$ & 10 & 0.056 & 0.333 & $0.974^{* * *}$ \\
\hline & 10 & $0-32$ & 10 & 0.083 & 0.253 & $0.990^{* * *}$ \\
\hline & 8 & $0-32$ & 10 & 0.079 & 0.309 & $0.986^{* * *}$ \\
\hline & 5 & $0-32$ & 10 & 0.121 & -0.009 & $0.986^{* * *}$ \\
\hline & 3 & $0-36$ & 11 & 0.118 & 0.137 & $0.995^{* * *}$ \\
\hline
\end{tabular}

Two and three asterisks show $p<0.01$ and $p<0.001$ of the significant level, respectively.

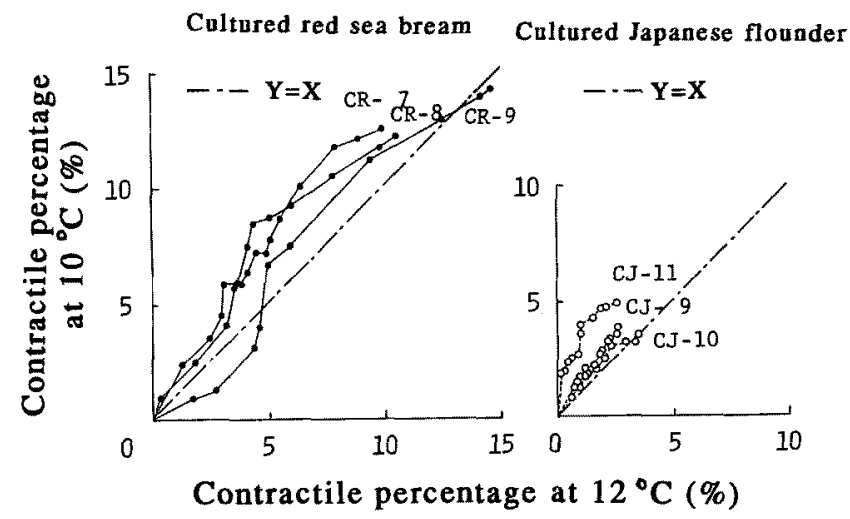

Fig. 3. The change of slope of regression line between the storage time and muscular contractile percentage with the storage temperatures in cultured red sea bream and cultured Japanese flounder.

tion of rigor mortis and the time elapsed to complete rigor mortis were both faster in red sea bream than in place. Our results agreed well with their findings.

In both fish species, though the progression speed of muscular contraction slowed with the decrease of storage temperature within the range from 25 to $12^{\circ} \mathrm{C}$, within the range under $10^{\circ} \mathrm{C}$, it became faster. Namely, the storage temperature at which cold rigor mortis appeared was near $10^{\circ} \mathrm{C}$ in both fish species. As for these results in the case of common rigor mortis which slowed in progression speed of muscular contraction with a decrease of storage temperature and in the case of cold rigor mortis which progressed faster with a decrease of storage temperature, a possible cause for the former case of common rigor mortis is the decrease of myofibrillar $\mathrm{Mg}^{2+}$-ATPase activity with the decrease of storage temperature. Regarding the possible cause for the latter case of cold rigor mortis, Watabe et $\left.a l{ }^{17}\right)$ had reported that the $\mathrm{Ca}^{2+}$-uptake rate of sarcoplasmic reticulum was decreased rapidly by cold shock $\mathrm{Ca}^{2+}$

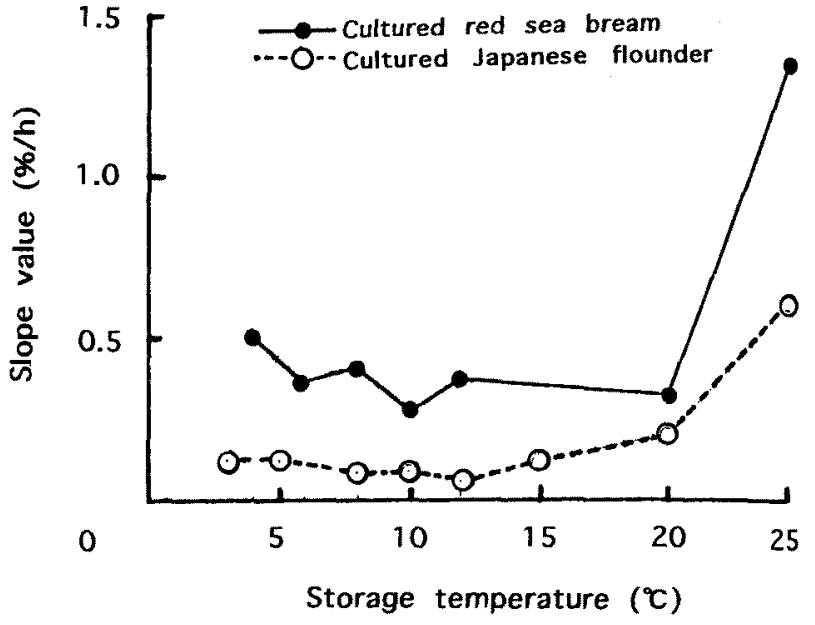

Fig. 4. The relationship between the muscular contractile percentages at 12 and $10^{\circ} \mathrm{C}$ of storage temperature in muscles cut off from the same specimen by cultured red sea bream and cultured Japanese flounder. The muscular contractile percentage value at $10^{\circ} \mathrm{C}$ of storage temperature was plotted against that at $12^{\circ} \mathrm{C}$ of storage temperature with the lapse of storage time.

concentration surrounding myofibril was increased continuously, which increased myofibrillar $\mathrm{Mg}^{2+}$-ATPase activity. Therefore, in both cases of common rigor mortis and cold rigor mortis, it was considered that the change of progression speed of rigor mortis with the decrease of storage temperature was caused by the change of myofibrillar $\mathbf{M g}^{2+}$-ATPase activity.

The possible cause for the difference of progression speed of rigor mortis between both fish species was considered to have been caused by the difference of myofibrillar $\mathrm{Mg}^{2+}$-ATPase activity. Iwamoto et al., ${ }^{1,4,5,12)}$ however, found almost no correlation between the progression speed of rigor mortis and the total amounts of ATP resolution in red sea bream, Japanese flounder, and several sea water fishes. Therefore, it is conjectured that the difference might be caused by the difference of character in myofibrillar $\mathrm{Mg}^{2+}$-ATPase or the difference of contractile mechanism in actomyosin between both fish species.

\section{References}

1) M. Iwamoto, H. Yamanaka, H. Abe, S. Watabe, and K Hashimoto: Rigor-mortis progress and its temperature-dependency in several marine fishes. Nippon Suisan Gakkaishi, 56, 93-99 (1990).

2) M. Bito, K. Yamada, Y. Mikumo, and K. Amano: Studies on rigormortis of fish-1. Difference in the mode of rigor-mortis among some varieties of fish by modified Cutting's method. Bull. Tokai Reg. Lab., 109, 89-96 (1983)

3) S. Watabe, H. Ushio, M. Iwamoto, M. Kamal, H. Ioka, and K. Hashimoto: Rigor-mortis progress of sardine and mackerel in association with ATP degradation and lactate accumulation. Nippon Suisan Gakkaishi, 55, 1833-1839 (1989).

4) M. Iwamoto, H. Yamanaka, S. Watabe, and K. Hashimoto: Comparison of rigor mortis progress between wild and cultured plaices. Nippon Suisan Gakkaishi, 56, 101-104 (1990).

5) M. Iwamoto, H. Ioka, M. Saito, and H. Yamanaka: Relation between rigor-mortis of sea bream and storage temperature. Nippon Suisan Gakkaishi, 51, 443-446 (1985).

6) R. W. H. Parry, M. V. Alcasid, and E. B. Panggat: Cold shock in fish; its characteristics in big head. International J. Food Sci. and 
Tech., 22, 637-642 (1987).

7) C. A. Curren, R. G. Poulten, A. Brueton, and N. S. D. Jones: Cold shock reaction in ice tropical fish. J. Food Tech., 21, 289-299 (1986).

8) M. Iwamoto, H. Yamanaka, S. Watabe, and K. Hashimoto: Effect of storage temperature on rigor-mortis and ATP degradation in plaice Paralichthys olivaceus muscle. J. Food Sci., 52, 1514-1517 (1987).

9) S. Mochizuki and A. Sato: Effect of various killing procedures and storage temperature on postmorterm changes in the muscle of horse mackerel. Nippon Suisan Gakkaishi, 60, 125-130 (1994).

10) K. Amano, M. Bito, and T. Kawabata: Handling effect upon biochemical change in the fish muscle immediately after catch-1; Difference of glycolysis in the frigate mackerel killed by various methods. Nippon Suisan Gakkaishi, 19, 487-498 (1953).

11) H. Oka, K. Ohno, and J. Ninomiya: Changes in texture during cold storage of cultured yellow tail meat prepared by different killing methods. Nippon Suisan Gakkaishi, 56, 1673-1678 (1990).

12) R. W. Korenon, T. C. Lainer, and F. Giesbrecht: An evalution of simple methods for following rigor development in fish. J. Food Sci., 55, 346-348 (1990).
13) M. Iwamato and H. Yamanaka: Remarkable differences in rigor mortis between wild and cultured specimens of red sea bream Pagrus major. Nippon Suisan Gakkaishi, 52, 275-279 (1986).

14) G. C. Whang, H. Ushio, S. Watabe, $M$. Iwamoto, and $K$. Hashimoto: The effect of thermal acclimation on rigor mortis progress of carp stored at different temperatures. Nippon Suisan Gakkaishi, 57, 541-548 (1991).

15) H. Abe and E. Okuma: Rigor-mortis progress of carp acclimated to different water temperatures. Nippon Suisan Gakkaishi, 57, 20952100 (1991)

16) S. Watabe, G. C. Hwang, H. Ushio, and K. Hashimoto: Changes in rigor mortis progress of carp induced by temperature acclimation. Agric. Biol. Chem., 54, 219-221 (1990).

17) S. Watabe, H. Ushio, M. Iwamoto, H. Yamanaka, and $K$. Hashimoto: Temperature dependency of rigor-mortis of fish muscle $\mathrm{Mf}-\mathrm{Mg}^{2+}$-ATPase activity and $\mathrm{Ca}^{2+}$-uptake by sarcoplasmic reticulum. J. Food Sci., 54, 1107-1115 (1989).

18) M. Tsuchimoto, T. Yamaga, K. H. Lee, $Z$. Wu, T. Misima, and $K$. Tachibana: The influence of $\mathrm{Ca}^{2+}$ concentration around myofibrillar $\mathrm{Mg}^{2+}$-ATPase on the speed and pattern of rigor mortis in fish species or cultured and wild fish. Fisheries Sci., 64, 148-154 (1998). 